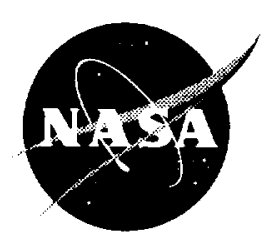

\title{
Recent GRC Aerospace Technologies Applicable to Terrestrial Energy Systems
}

M. David Kankam, Valerie J. Lyons, Mark A. Hoberecht, Robert R. Tacina, and Aloysius F. Hepp

Glenn Research Center, Cleveland, Ohio

Prepared for the

35th Intersociety Energy Conversion Engineering Conference

sponsored by the American Institute of Aeronautics and Astronautics

Las Vegas, Nevada, July 24-28, 2000

National Aeronautics and

Space Administration

Glenn Research Center

July 2000 


\section{Acknowledgments}

The authors express their sincere gratitude to the following GRC individuals for their assistance, review, and constructive comments in preparing this paper: Raymond F. Beach, Dr. Daniel L. Bulzan, Robert M. Button, James E. Cairelli, James E. Dudenhoefer, Dr. Chi-Ming Lee, Lee Mason, Kerry L. McLallin and Lanny G. Thieme.

Trade names or manufacturers' names are used in this report for identification only. This usage does not constitute an official endorsement, either expressed or implied, by the National Aeronautics and Space Administration.

Available from

NASA Center for Aerospace Information

7121 Standard Drive

Hanover, MD 21076

Price Code: A03
National Technical Information Service 5285 Port Royal Road Springfield, VA 22100

Price Code: A03 


\title{
TERRESTRIAL ENERGY SYSTEMS
}

\author{
M. David Kankam, Valerie J. Lyons, Mark A. Hoberecht, \\ Robert R. Tacina, and Aloysius F. Hepp \\ National Aeronautics and Space Administration \\ Glenn Research Center \\ Cleveland, $\mathrm{OH} 44135$
}

\begin{abstract}
This paper is an overview of a wide range of recent aerospace technologies under development at the NASA Glenn Research Center, in collaboration with other NASA centers, government agencies, industry and academia. The focussed areas are space solar power, advanced power management and distribution systems, Stirling cycle conversion systems, fuel cells, advanced thin film photovoltaics and batteries, and combustion technologies. The aerospace-related objectives of the technologies are generation of space power, development of cost-effective and reliable, high performance power systems, cryogenic applications, energy storage, and reduction in gas-turbine emissions, with attendant clean jet engines. The terrestrial energy applications of the technologies include augmentation of bulk power in ground power distribution systems, and generation of residential, commercial and remote power, as well as promotion of pollution-free environment via reduction in combustion emissions.
\end{abstract}

\section{INTRODUCTION}

The NASA Glenn Research Center (GRC) has long been a major developer of, and contributor to, key technologies for NASA's missions and programs. Joint and collaborative efforts have included participation by other NASA Centers, U.S. government agencies, industry and academia. This paper discusses some recent GRC aerospace technologies with potential benefits to terrestrial energy systems. Overviews of combustion and power technologies, namely, space solar power (SSP), power management and distribution (PMAD), flywheel, Stirling cycle conversion systems, fuel cells and thin film technologies are provided.

Copyright $(0) 2000$ by the American Institute of Aeronautics and Astronautics, Inc. No copyright is asserted in the United States under Title 17, U.S. Code. The U.S. Government has a royalty-free license to exercise all rights under the copyright claimed herein for Governmental purposes. All other rights are reserved by the copyright owner.
The objective of NASA's 'Space Solar Power Exploratory Research and Technology (SERT) program is to use a constellation of satellites to beam Gigawatts of space solar energy-derived power to a terrestrial power system, using large rectennas. The beamed power is microwave-based and, has low loss at $5.8 \mathrm{GHz}$. Ref. [1] gives a comprehensive digest of the SERT program. The program goal is to augment a projected shortfall of global electric power supply. The shortfall is expected to result from widespread high demand for, and consumption of energy. One GRC role is to develop the technologies for SSP power generation and advanced power management and distribution (PMAD).

To enhance solar energy collection for power generation, GRC leads an effort to develop thin film solar cells to allow the deployment of a large number of solar cells. The potential features of light mass, low cost and high production make thin film solar cells ideally attractive to, and suitable for packaging large arrays in launch vehicles. In-house GRC research efforts aim at developing low temperature growth processes for thin film solar cells.

The goals of the PMAD technology development are low cost, high reliability and high performance of the associated system(s), with emphasis on automation, dual use, modularity and performance. The modular, power converter-dominant PMAD and related electronics-based systems are key technologies for NASA's Earth Science, Human Exploration and Development of Space (HEDS) and Aero-Space Enterprises. For example, the converters and electronic systems are expected to play an important role in missions of all NASA Enterprises.

The flywheel technology focuses on energy storage and peak power applications. This effort, in combination with concurrent development of corresponding component technologies, is an advancement of previous efforts by the participants ${ }^{[2]}$. A key objective of the present technology development is to demonstrate high performance, high reliability and reduced losses in a high-speed, lightweight flywheel energy system (FES). 
The Stirling cycle conversion technology development effort seeks to produce free-piston Stirling power converters for space and solar terrestrial power generation applications. A major advantage of the Stirling engine is its ability to use any type of heat source. Other attractions of free-piston Stirling machines are their long life, reliability and high thermodynamic efficiency. Stirling converter-based radioisotope power systems for deep space applications, and free-piston Stirling cycle (FPSC) refrigerator/freezer $(R / F)$ technology for manned space exploration are discussed.

Fuel cell technology is highlighted in a focussed terrestrial application project in which GRC and its collaborators are applying fuel cell technology to the design and operation of a new energy-efficient building at Oberlin College in Ohio. The ecologically-designed Adam Joseph Lewis Center for Environmental Studies "serves as a pedagogical tool which encourages mindfulness of materials selection, wastewater recycling, and full cost accounting for the building's technologies and structure". In this joint endeavor, GRC leads the application of renewable energy systems, notably those pertaining to fuel cell and solar cell technology.

Finally, an on-going, GRC combustor research program seeks to reduce nitrogen oxide, NOx, emissions from aircraft gas turbines. This effort is expected to contribute to other ground-based NOx emissions reduction efforts

The following summaries of these technologies describe their aero-space applications as well as their applicability to terrestrial energy systems.

\section{POWER TECHNOLOGIES}

\subsection{SPACE SOLAR POWER (SSP)}

Solar photovoltaic (PV) systems have been the conventional 'workhorse' for generating space power. A joint GRC-Industry technology demonstration has shown that a closed Brayton-cycle (CBC)-based solar dynamic (SD) power system is, also, a viable means to generate space power ${ }^{[3]}$. In an SD system, a highly efficient heat engine converts solar energy to electric power. Compared to other heat engines such as the Rankine and Stirling engines, the CBC unit is viewed as particularly attractive for space solar power (SSP) generation, due to its high power scalability and relative maturity. In-house research efforts at GRC have further reinforced the viability of SD power technology as an option for the SSP system. The results of the GRC in-house effort suggest that the introduction of modular systems, exemplified by the SD power system of Fig. 1, can enable the attainment of GW power levels required for the SSP system ${ }^{1+]}$. Such modularity will, also, have the benefit of facilitating in-orbit assembly of constituent parts to form a space power system.

Reference [4] identifies the needed near-term advanced component development and far-term technology infusion, for the realization of an SSP system. The required items include lightweight deployable solar concentrators and composite material radiators, among others. Current work is focused on proof-of-concept research and technology development of an SD power option for SSP. Complementary to the needed advances is an advanced PMAD for the associated power system(s).

\subsection{ADVANCED PMAD}

The acronym PMAD denotes power management and distribution of electric power flow from a power generation source to load(s) at transmitting and receiving centers. Associated functions of PMAD are the conditioning and coordinated control of power to the distribution network of the power system. Automation, dual use and modularity will be incorporated in the development. This is consistent with the goals of advanced PMAD, namely, low cost, high reliability and performance. Automation will be realized via advancements in converters and system controls, and in integrated power and converter busses. Dual use will be achieved by implementing hardware commonality for air/spacecraft, and by developing hardware tolerance of radiation-induced single event upset (SEU). Modularity will be built into the advanced, topology-varied power converters, integrated electronic switches, also known as integrated power modules (IPMs), and power electronics-based systems. The development of modular converters with built-in intelligent controls will be based on power electronic building blocks (PEBBs) technology ${ }^{[5]}$. The cost reduction of the modular PMAD will be sought through the use of common controllers and components for the various modules with built-in reliability.

A considerable portion of the real estate in aerospace power systems is power electronics-based. Similar to terrestrial power systems, it is projected that power electronics will increasingly penetrate aerospace power systems. This projection is based on anticipated 'more electric' upgrades in aerospace vehicles, such as aircraft, reusable launch vehicles and the shuttle. There is a wide array of applicable options for the 'more electric' technology ${ }^{[6]}$. The advent of PEBBs and their subsequent insertion into PMAD systems is expected to facilitate the control of PMAD, aid in troubleshooting 
system and subsystem malfunctions, and to improve the overall reliability of the power system. The consequent attributes of an advanced PMAD are high efficiency, high power density, particularly of the embedded passive components, and advanced packaging and thermal management. Fig. 2 illustrates the thrusts of GRC's advanced PMAD program. The relevance of the modular converters and related systems to NASA missions is depicted in Fig. 3.

\subsubsection{MODULAR POWER CONVERTERS}

GRC's development of radiation-tolerant, intelligent modular power converters is jointly undertaken with industry and academia. The industrial partner is TRW. Academia participants are Texas A \& M University, Cleveland State University, the University of Minnesota, Auburn University and the University of Illinois. Also, the Prairie View University is studying radiation effects on DC-DC converters. This teaming approach assures commercial and industrial applicability of the converters, and infusion of innovation, while concurrently maintaining relevance to NASA's aerospace programs and missions. Industry is responsible for the development of advanced converter topologies, for integration with digital controllers. Academia focuses on advanced converter topologies, integrated magnetics, and state-of-the-art digital control algorithms and associated hardware for DC-DC converters. The digital control algorithms will provide controller requirements for desired features of the converters. GRC in-house work includes the development of a supervisory controller for the modular components, and PEBB-based motor drive technology with advanced controls. Recently, GRC has developed digital controls which significantly reduced the size of input filter requirements for modular DC-DC converters, and with no adverse effect on power quality specifications ${ }^{[7] .}$ The anticipated gain in power density and reduction in parts count, derived from modularity in power converters, is typified in Fig. 4.

Planned incorporation of adaptive control and automatic reconfiguration of the modular converters should measurably improve their reliability and fault tolerance, for both aerospace and terrestrial applications. The infusion of digital and intelligent controls in the converter technology is expected to enhance the development of distributed, modular PMAD for relatively large systems.

The beneficiaries of advanced, modular PMAD include spacecraft, aircraft and launch vehicles (LVs) in the aerospace arena, and other types of terrestrial power and propulsion systems. For space systems in particular, modularity will yield reductions in size and weight of power processing units (PPUs) for electric propulsion and photovoltaic (PV) array/battery regulators for high density PMAD architectures. Similar gains in power electronics-based systems, especially motor drives and their advanced controls, will benefit flywheel systems for spacecraft, and electric actuation for thrust vector control (TVC) of LVs and control surfaces of aerospace vehicles, in general. Terrestrially, electric and hybrid electric vehicles (EVs, HEVs) and other industrial drives will, also, benefit from advanced PMAD.

\subsection{FLYWHEEL SYSTEMS}

NASA GRC, US Air Force (USAF), DARPA, National Reconnaissance Office (NRO), Department of Transportation (DOT), US Flywheel, Inc., and TRW are collaborating to develop advanced flywheel technologies, with focus on energy storage and peak power applications. Flywheel energy storage (FES) applications require high specific energy and, hence, high rotor speeds, robust rotor structure and magnetic bearings. Other participants in related on-going technology developments in lightweight composite materials, high performance magnetic bearings and power electronics-based systems, include the Oak Ridge National Laboratory, Boeing Company, the University of Texas Center for Electro-Mechanics (UT-CEM), Auburn University and American Flywheel Systems, Inc. The first flight demonstration of flywheel technology is planned for the International Space Station (ISS). Currently proposed chemical batteries have only five years life, and their narrow temperature tolerance range $\left(10^{\circ} \mathrm{C}\right)$ is far exceeded by the operational temperature range of flywheels. The higher energy density (W-hr/lbm) of flywheels is a source for potential peak power, if needed during shuttle docking with the ISS. The cited flywheel advantages can translate into lower operational costs for the ISS.

Consistent with the objectives of high performance, high reliability and reduced losses in a high-speed, lightweight FES, a significant recent milestone achievement for the GRC-USAF-TRW effort has been the operation of an advanced FES system at 60,000 RPM. This success not only demonstrates the highest speed to-date by a flywheel spun on magnetic bearings, but also, strengthens the viability of using a FES system, rather than chemical batteries, on the ISS. The success of the U.S. Flywheels-built FES system is a culmination of advanced composite materials-based rotor, low-loss magnetic bearings, high-speed motorgenerator set and motion control algorithms. A cutaway view of the FES system is depicted in Fig. 5. 
FES system applications typically require two counterrotating flywheels with resultant, no-disturbance net torque, and momentum (derived from reaction wheels) for attitude control. GRC is pursuing a parallel in-house effort to combine a FES system and an attitude control system (ACS) into a single architecture, namely, integrated power and attitude control system (IPACS). With its expected significant mass reduction, the IPACS is viewed as an enabler to the achievement of lightweight, low cost and significantly capable spacecraft. Studies-to-date predict that the specific energy of flywheel-based IPACS can be as high as ten times the current specific energy of batteries and reaction wheels used on midsize spacecraft with energy levels in excess of $200 \mathrm{~W}$-Hrs. This is based on a projected availability of high performance composites used in the flywheel rotor. Also, the attendant numerous charge/discharge cycles of the lower earth orbiting (LEO) satellites make the IPACS particularly suitable to this class of spacecraft. Potential space applications for the IPACS encompass LEO satellites for earth observation and reconnaissance, and planetary outposts and rovers. Likely ground-based uses include general transportation systems, particularly, electric and hybrid electric vehicles (EVs, HEVs), and uninterruptible power supplies (UPS) for launch operations.

The other objective of the flywheel technology development, that is, peak power or load leveling application, depends on the timeliness with which the system responds to demands for rapid and large increases in loads. Unlike most of current generation satellites with mainly level loads, future LEO communication satellites are expected to experience considerable peak power demands, during city- or ground station-fly-over-activated transmission. IPACS are projected to suitably serve the peak power needs of future communication satellites. EVs and HEVs and their charging stations constitute terrestrial application areas for peak power capability of flywheel systems.

The GRC has established a goal of providing a fully developed and flight qualified flywheel system for ISS demonstration by late 2004. A successful integration of advanced flywheels into future spacecraft systems will generate advanced flywheel technology and opportunities for other aerospace and terrestrial applications.

\subsection{STIRLING CYCLE CONVERSION SYSTEMS}

The inherent advantages of long life, reliability and high thermodynamic efficiency make the Stirling cycle conversion system attractive for space and terrestrial applications. GRC has conducted research and technology development on Stirling systems since the mid-1970's. Initial efforts were to develop a crank- driven alternative engine for automotive propulsion. Other past work has included development of a $12.5 \mathrm{kWe}$ converter (i.e. coupled free-piston Stirling engine (FPSE)-linear alternator) for a (space power) SP-100 nuclear power system ${ }^{[8]}$, using a heat pipe thermal input and operated at an overall temperature ratio of 2 . This system achieved its power and efficiency goals during 1500 hours of endurance tests, on its first startup. As part of the SP-100 Stirling technology development, various in-house testing and analyses have been completed. These efforts encompassed testing the space power research engine (SPRE) ${ }^{[9]}$, improving the understanding of Stirling thermodynamic losses ${ }^{[10]}$, permanent magnet characterization $^{[1]}$, and test-verified dynamic analyses of a Stirling converter-load system ${ }^{[12]}$. Reference [12] discusses the system performance and control requirements for the converter feeding a dynamic reactive load. Also, in the past, GRC has technically managed the Advanced Stirling Conversion System (ASCS) terrestrial dish free-piston Stirling project ${ }^{[13]}$. This paper discusses more recent interagency-industry Stirling technology developments for radioisotope space power and refrigerator/freezer (R/F) systems.

NASA GRC, Department of Energy (DOE) and Stirling Technology Company (STC) are developing a 55We Stirling converter for a high efficiency Stirling radioisotope power source, to provide spacecraft onboard electric power for future NASA deep space missions. Radioisotope Thermoelectric Generators (RTGs), traditionally the 'workhorse' for electric power requirements for outer planetary space probes, have relatively low efficiency ( 5 to 7 percent) and high radioisotope, namely, plutonium, inventory. The projected 20 to 25 percent efficiency of the Stirling power source, with its attendant over 60 percent reduction in the radioisotope inventory, makes such a power source attractive with regard to fuel cost and environmental safety, as a replacement for the RTG source. The role of GRC in the Stirling converter development is to determine the converter performance in launch and orbit transfer load conditions, assess the engine heater head structural life, characterize permanent magnet aging, and perform finite element analysis (FEA) of the alternator design.

Other key issues, such as the operation of multiple Stirling converters and adaptive reduction of Stirling converter vibrations, are being pursued under GRC. managed, NASA-sponsored Small Business Innovative Research (SBIR) projects by STC. For example, STC has successfully demonstrated synchronous operation of a pair of thermodynamically independent Stirling converters $^{[14]}$. Figure 6 shows a set-up of a pair of Stirling converters synchronized by parallel connection 
of the linear alternators of the converters, with a rigid mechanical coupling between the housings of the two converters. The thermodynamic independence of the converters makes them potentially redundant, to safeguard against a converter failure and to promote uninterruptible power generation. Further, the mechanically arranged $180^{\circ}$ out-of-phase operation of the two converters yields significant reduction in their vibrations, without resorting to feedback controls. Finally, an evaluation of an artificial neural network (ANN) indicates its potential for converter health monitoring.

The objective of another SBIR project with STC is to develop an Adaptive Vibration Reduction System (AVRS), to provide further significant reduction in converter vibrations during normal operating mode, and to enable adjustment to changing converter conditions over the course of a mission ${ }^{[1+1}$. The achievements of multiple converters-load system operation and vibration reduction in the synchronized converters strengthen the viability of Stirling converters to replace RTGs, for radioisotope power systems for space missions.

GRC is collaborating with NASA Ames Research Center (ARC) and Marshall Space Flight Center (MSFC) and the US Air Force to demonstrate a refrigeration system for long-term storage of cryogenic fluids for space missions using an advanced high efficiency pulse tube cooler. Stirling cycle and pulse tube coolers are attractive for their high efficiency and low vibration. They are developed primarily for sensor cooling for which low vibration is critical. A pulse tube cooler is similar to, but has fewer moving parts than, a Stirling cycle cooler. These coolers are under consideration by NASA for applications such as Refrigerator/Freezer (R/F) systems for food, medical supplies and biological sample storage, long-term storage of cryogenic propellants, and cooling superconductors for solar space power. Earlier, a GRC assessment identified the needed, advanced $R / F$ technologies for future Life and Biomedical Sciences space missions ${ }^{[15]}$. That assessment sought to subsequently develop key technologies, and design, fabricate and demonstrate the developed technologies by testing a brassboard R/F system. In the present effort, GRC is attempting to aid industry, wherever possible, in developing a manufacturing base and reducing the unit cost for the coolers, to assure their widespread availability to users and, thereby, reduce development costs for NASA applications. GRC, ARC and MSFC are performing in-house analyses, and developing technologies to modify commercially available coolers to suit NASA needs. The most likely applicable NASA platforms are the Shuttle, the
International Space Station and planetary probes. Also, part of the GRC work focuses on developing controls to run multiple coolers, with view to limit their vibrations and tolerate failure of any one cooler.

A number of possible terrestrial applications of the above technologies are under consideration. The $55 \mathrm{We}$ Stirling converter for the radioisotope power system is being evaluated for remote power applications. A vibration balancing technique, developed as part of the NASA SBIR project at STC, has been selected for inclusion in technology development for a naval application. A possible use of an ANN is under active consideration by manufacturers interested in various uses of Stirling engines. The applications of coolers encompass solar-powered refrigeration for off-grid operation, particularly in a tropical climate, heat pumps, and residential use to eliminate chlorinated fluoro carbons (CFC) from home refrigeration ${ }^{[16]}$. Cooler technology penetration into the residential market will be enhanced when pricing can become competitive with current technology for home refrigeration.

\subsection{FUEL CELL}

GRC has actively researched fuel cells mainly for space applications. In recent years, there have been considerable advancements in fuel cell technology. In addition to its use in space, a fuel cell offers significant potential as a source of primary power for both the automotive industry and residential market. However, a fuel cell can be more than just a source of primary electric power; it can be combined with a water electrolyzer and gas storage tanks to form a regenerative fuel cell (RFC) energy storage system, as shown in Fig. 7. The RFC system acts as a battery, which stores energy in the form of gaseous hydrogen and oxygen during periods of excess energy availability, and then draws on that energy reserve to produce power, when needed. This capability is especially attractive, if the source of excess energy is a renewable power system, such as solar or wind, which is typically intermittent and seasonal in nature.

In collaboration with Oberlin College, community leaders and William McDonough \& Partners (architectural firm), GRC has applied the renewable energy feature of RFCs to the design of a revolutionary building, the "Adam Joseph Lewis Center for Environmental Studies' at Oberlin College. The Lewis Center will have solar photovoltaic panels on its roof, as well as several possible wind generators on site. The intermittent and seasonal characteristics of the renewable sources are such that the building will have to rely on another power source, when the renewable 
sources are insufficient. At other times, an excess of renewable energy will be available to meet the electrical loads of the building.

RFC systems offer a major advantage over battery systems in that the power and energy portions of an RFC system are independent of each other. This means that capacity can be increased in an RFC system by simply adding more storage tanks, without having to increase the size of the fuel cell or electrolyzer. The capacity of battery systems can be increased, only by adding more batteries. Seasonal energy storage is, therefore, impractical for battery systems, due to the large quantities of batteries required to store excess summer electrical energy for winter use. With sufficient reactant storage, RFC systems can easily accomplish this task. The Lewis Center will generate an excess of solar power during the summer months, because solar generation will be high and building electrical loads will be low. Sufficient reactant storage will allow some of this excess energy to be used during winter months when solar power is low, and building energy loads are high.

Regarding terrestrial applications, another advantage of RFC systems over battery systems is their adaptability to the intermittent nature of wind generators. On extremely windy days when excess wind power is very high, batteries will reach their 100 percent state-ofcharge limit and not be able to store all of the available energy. In contrast, RFC systems can easily store excess energy. Even if building energy loads are high, the potential exists to produce an excess of wind power. As wind power is proportional to the cube of wind speed, a series of extremely windy days can generate a significant amount of stored energy for later use.

The Adam Joseph Lewis Center for Environmental Studies at Oberlin College will serve as an excellent demonstration site for combining RFC energy storage with solar and wind power sources, to form a completely renewable energy system. The unique nature of RFC energy storage will demonstrate the practicality of renewable energy systems for areas such as northern Ohio, a region not thought to be appropriate for renewable sources. NASA GRC will continue to work with Oberlin College throughout the design, installation, and demonstration of their renewable energy system, while promoting the use of RFC energy storage systems for other aerospace and terrestrial applications.

\subsection{THIN FILM TECHNOLOGIES}

Among the desirable attributes in any space-bound component, subsystem or system, are high specific power (to minimize cost of payload launch into space), radiation tolerance and high reliability, without sacrificing performance. GRC is currently developing space-bound technologies in thin film chalcopyrite solar cells and lithium polymer batteries. These technologies are described below.

High specific power (watts/kg) space solar arrays can be achieved by developing a high-efficiency, thin-film solar cell which can be fabricated directly on a flexible, lightweight, space-qualified durable substrate such as Kapton (Dupont), or other polymide, or suitable polymer film. Cell efficiencies approaching 20 percent at AMO (air mass zero) will be required to compete with state-of-the-art crystalline materials. Current thinfilm cell fabrication approaches are limited by either (1) the ultimate efficiency that can be achieved with the device material and structure, or (2) the requirement for high-temperature deposition processes that are incompatible with all presently known flexible polymides, or other polymer substrate materials. GRC is developing a chemically based approach to enable the development of a process which will produce highefficiency cells at temperatures below $500^{\circ} \mathrm{C}$. Such low temperatures minimize the problems associated with the difference between the coefficients of thermal expansion of the substrate and thin-film solar cell and/or decomposition of the substrate.

Polymer substrates can be used at low temperatures. As such, thin-film solar cell materials can be deposited onto molybdenum-coated Kapton, or other suitable substrates, via a chemical spray process, using advanced single-source precursors, or by direct electrochemical deposition. A single-source precursor containing all the required chemically-coordinated atoms such as copper, indium, sulfur and others, will enable the use of low deposition temperatures that are compatible with the substrate of choice ${ }^{[17]}$. A combination of low-temperature electrochemical deposition and chemical bath deposition has been used to produce $\mathrm{ZnO} / \mathrm{CdS} / \mathrm{CuInSe} \mathrm{S}_{2}$ thin-film photovoltaic solar cells on lightweight flexible plastic substrates, depicted in Fig. $8^{[18]}$. Expected low manufacturing cost and improved reliability of many high-technology polymers make the thin-film technology potentially applicable to terrestrial systems. Examples include offgrid applications such as military field operations, remote housing or communications stations, as well as, recreational or marine applications.

GRC is, also, engaged in polymer-based thin-film battery technology for space applications. Specifically, thin-film lithium hybrid batteries have been integrated with Multi-Chip Modules (MCM's) for possible use in micro- and nano-satellites. The same fabrication process has been used to develop an all solid-state lithium battery, Fig. 9, from commercially obtained 
polymer electrolytes. The flexibility of the materials, techniques and infrastructure allows the use of any number of free-standing polymer electrolytes or a variety of cathode and anode materials. The outer layer of the GRC-developed batteries is space-qualified, lightweight and flexible Kapton which is radiation- and temperature- tolerant. The anode and cathode sandwich the polymer electrolyte of the lithium battery ${ }^{[19]}$.

Near-term applications of thin-film Lithium batteries include pacemaker, hearing aid and related biomedical devices, computers and cell phones. Other beneficiaries are propulsion, power and communications for commercial and military applications. Mid-term uses for integrated power devices (described above), can encompass a combined battery and solar cell in a roof tile to generate residential power, or solar-rechargeable power system for the military, recreational vehicles and other consumer products.

\section{COMBUSTION TECHNOLOGY}

In addition to aerospace power technology, GRC is NASA's Center of Excellence for Turbo-machinery. Part of the turbo-machinery research effort includes combustion emissions reduction. The expected contributions of advanced combustor research at GRC include liquid fueled low NOx combustor concepts, computational fluid dynamics (CFD) modeling, ceramic liners, acoustic instability modeling and control, and a particulate emissions database. Fig. 10 shows the roadmap of the various technology readiness levels (TRLs) for the low NOx emission combustor development. Joint research programs with industry include full-scale combustor tests of low emission gas turbine combustors primarily for aircraft engines. Much of this technology is also applicable to ground power gas turbine combustors.

Ground power gas turbines using natural gas produce very low levels of $\mathrm{NOx}$ emissions. However, engines which use liquid fuel have much higher NOx emissions. An objective of the GRC combustor program is to provide low NOx emission combustors which use liquid fuel or have dual fuel capability. Among the concepts under development are partially pre-mixed, pre-vaporized combustor, lean direct injection, and rich burn-quick quench-lean burn. At GRC, the emphasis is on lean direct injection which uses a multitude of small fuel injectors to improve the fuel-air mixing and, thus, reduce the amount of NOx. Photo-etched laminates are used, since they can increase the number of fuel injectors without increasing the overall complexity or cost of the development. Compared to conventional designs, flametube tests have demonstrated 80 percent reduction in NOx levels.
Efforts have been focused on developing a computational combustion capability, as part of a National Combustion Code to meet combustor designer requirements for model accuracy and analysis turnaround time. The solver of the Code is an analysis tool for turbulent combustion flows. The solver uses unstructured meshes and multiple processor machines, and is linked to computer-aided-design (CAD) systems, which incorporate solid modeling and automated meshing of complex geometries. The Code includes a nonlinear, k-epsilon turbulence model, a chemical kinetics model, a spray module, and a joint probability density method for species and enthalpy.

Non-intrusive laser diagnostic measurements are being taken of reacting flows at pressures up to $600 \mathrm{lb} / \mathrm{in}^{2}$. Such measurements can be used in combustor development and code validation. Specifically, measurements are made of hydroxyl $(\mathrm{OH})$ using planar laser-induced fluorescence, liquid fuel concentration using planar Mie scattering and luminescent emissions of $\mathrm{C}_{2}$, velocity using laser doppler velocimetry, and fuel dropsizes using a phase doppler method.

Ceramic (SiC) composite matrix (CMC) liners, currently under development, will have a temperature capability of $2400^{\circ} \mathrm{F}$. This will result in reduced combustor cooling levels of 10 to 15 percent of the combustion air, which is about half of the required amount for metal liners. With less air used for cooling liners, more air is available for use in the combustion process, thereby reducing the NOx levels.

Advanced controls for emissions and operability are being developed. Fuel staging can be used to reduce the NOx levels and improve combustion stability. A model under development for the acoustic instabilities in a Lean-Pre-mixed-Pre-vaporized combustor and Lean Direct Injection combustor will be used to control or prevent instabilities from occurring.

The Glenn Research Center's Particulate and Gaseous emissions Measurement System (PAGEMS) was developed to aid the design of environmentally friendly combustors. PAGEMS, a group of analyzers integrated and housed in a van, characterizes the particulate and gaseous species concentrations from the combustor exhaust, using extractive sampling techniques. Presently, a comprehensive aircraft particulate database does not exist. The data acquired by PAGEMS will help populate this database, which is important in the assessment of the impact of modern aircraft emissions, and/or ground power emissions, on the atmosphere. 


\section{SUMMARY}

This paper presents overviews of some recent aerospace power and combustion technologies pursued by GRC, in collaboration with other NASA Centers, government agencies, industry and academia. The research and technology efforts primarily support programs to enable NASA missions. Goals include generation of solar energy-based power to augment terrestrial power systems, development of advanced, modular PMAD for cost-effective, highly reliable and high performance power systems, and flywheel technology development for energy storage and peak power applications. Other efforts pertain to Stirling cycle conversion technologies for space, solar terrestrial power generation and cryogenic applications, fuel cells and thin film technologies for power generation. Combustion technology is being produced for reducing gaseous and particulate emissions from aircraft gas turbines.

The attendant terrestrial uses of the cited technologies include, respectively, boosting of terrestrial bulk power supply to meet increasingly high power demands, lightweight, advanced PMAD for industrial drives and automotive applications, Stirling cycle-based home refrigeration, and remote, residential and commercial power generation, and environmental control of combustion-induced emissions.

\section{REFERENCES}

[1] Dudenhoefer, J.E., George, P.J., "Space Power Satellite Technology Development at the Glenn Research Center", Presented at 'National Heat Transfer Conference', Pittsburgh. PA. Aug. 20-22, 2000.

[2] Christopher, D., Lt. Donet, C.. "Flywheel Technology and Potential Benefits for Aerospace Applications". Proc. of the IEEE Aerospace Conf.. pp. 159-166, 1998.

[3] Shaltens, R.K.. "Overview of Solar Dynamic Ground Test Demonstration Program at NASA Lewis Research Center". NASA Technical Memorandum TM-106876, March 1995.

[4] Mason. L.S., "A Solar Dynamic Power Option for Space Solar Power". Presented at the ' $34^{\text {th }}$ IECEC', Vancouver, BC, Canada, Aug. 1-5. 1999; NASA TM-209380.

[5] Elbuluk, M.E., Kankam. M.D.. "Power Electronics Building Blocks (PEBBs) in Aerospace Power Electronic Systems", Presented at the ' $34^{\text {th }}$ IECEC'. Vancouver, BC, Canada, Aug. 1-5, 1999.

[6] Elbuluk, M.E., Kankam, M.D., "Motor Drive Technologies for the Power-By-Wire (PBW) Program: Options, Trends and Tradeoffs", Proc. of IEEE/NAECON, Dayton, OH. May 22-26. 1995, vol. 1, pp. 511-522. NASA TM-106885.
[7] Button. R.M., Kascak. P.E., Lebron-Velilla, R., "Digital Control Technologies for Modular DC-DC Converters". Presented at the 'IEEE Aerospace Conference'. Big Sky. Montana, March 18-24, 2000.

[8] Dudenhoefer. J.E.. Winter, J.M., Alger, D., "Progress Update of NASA's Free-Piston Space Power Converter Technology Project", Presented at the "Nuclear Technologies for Space Exploration Conference', Jackson Hole, Wyoming. Aug. 16-19. 1992. NASA TM-105748.

[9] Cairelli. J.E., Geng. S.M., "Results from Baseline Tests of the SPRE I and Comparison with Code Model Predictions", Presented at the ' $24^{\text {th }}$ IECEC', Washington D.C. Aug. 6-11, 1989. NASA TM- 102044.

[10] Tew. R.C.. Geng. S.M., "Overview of NASA-Supported Stirling Thermodynamic Loss Research", Presented at the $27^{\text {th }}$ IECEC', San Diego. CA. Aug. 3-7. 1992. NASA TM-105690.

[11] Niedra. 3.M., "Comparative M-H Characteristics of 1-5 and 2-17 Type Samarium-Cobalt Permanent Magnets to $300^{\circ} \mathrm{C}$ ". NASA CR-194440, 1994

[12] Kankam, M.D., Rauch, J.S., "Transient and Steady-State Performance of Space Power Research Engine with Resistive/Motor Loads", Proc. of the 31 ${ }^{\text {st }}$ IECEC. Aug. 11-16. 1996, vol. 2, pp. 1277-1282.

[13] Shaltens, R.K., Schreiber. J.G.. "Status of the Advanced Stirling Conversion System Project for $25 \mathrm{kWe}$ Dish Stirling Applications", Presented at the '26 ${ }^{\text {th }}$ IECEC'. Boston, MA. Aug. 4-9. 1991. NASA TM-104528.

[14] Thieme, L.G.. Qui, S., White, M.A., "Technology Development for a Stirling Radioisotope Power System". Presented at the ' 2000 STAIF Conf.', Albuquerque, NM.

[15] Cairelli. J.E.. Gaseor, T., "NASA Life Sciences Advanced Refrigerator/Freezer Technology Assessment Results". Presented at the ' $26^{\text {th }}$ International Conf. on Environmental Systems'. Monterey, CA, July 8-11, 1996. NASA TM-107225.

[16] Berchowitz, D.M., "Stirling Coolers for Solar Refrigerators", Presented at the 'International Appliance Technical Conference'. Purdue University. W. Lafayette. IN, May 13-15, 1996.

[17] Hollingsworth. J.A.. Hepp. A.F., Buhro, W.E.: "Spray CVD of Copper Indium Sulfide Films: Control of Microstructure and Crystallographic Orientation". Chemical Vapor Deposition, vol. 3, pp. 105-108, 1999.

[18] Raffaelle, R.P et al., "Chemically Deposited Thin-Film Solar Cell Materials", Presented at 'SPRAT XVI', Cleveland, $\mathrm{OH}$, Aug. 31-Sept. 2. 1999. NASA Conf. Proc. (2000).

[19] Raffaelle, R.P.. Harris. J.D, Rybicki. G.C.. Scheiman, D.A. and Hepp,A.F., "A Facile Route to Thin Film Solid State Lithium Microelectronic Batteries", Journal of Power Sources, in Press. 2000. 


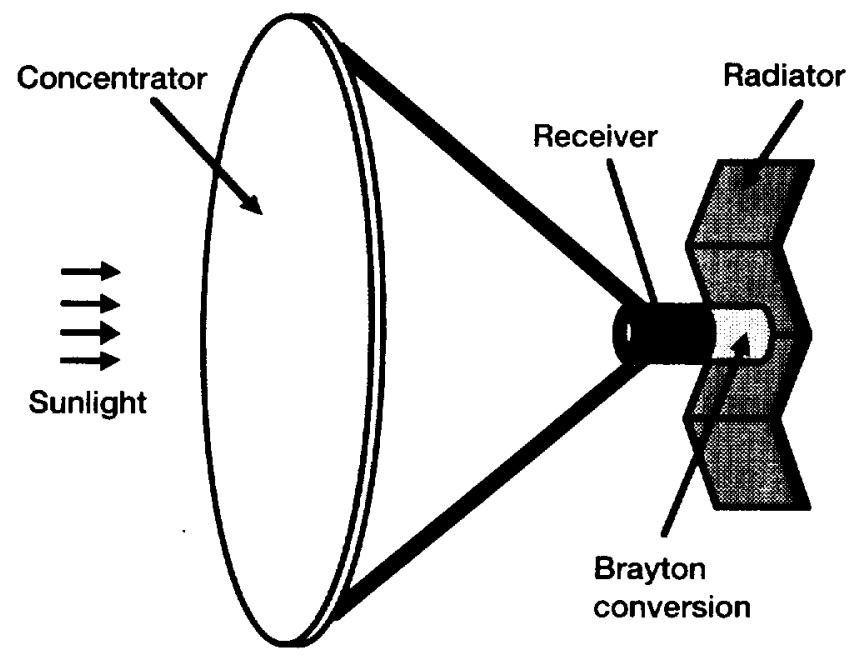

Figure 1.-Modular Solar Dynamic (SD) Power System.

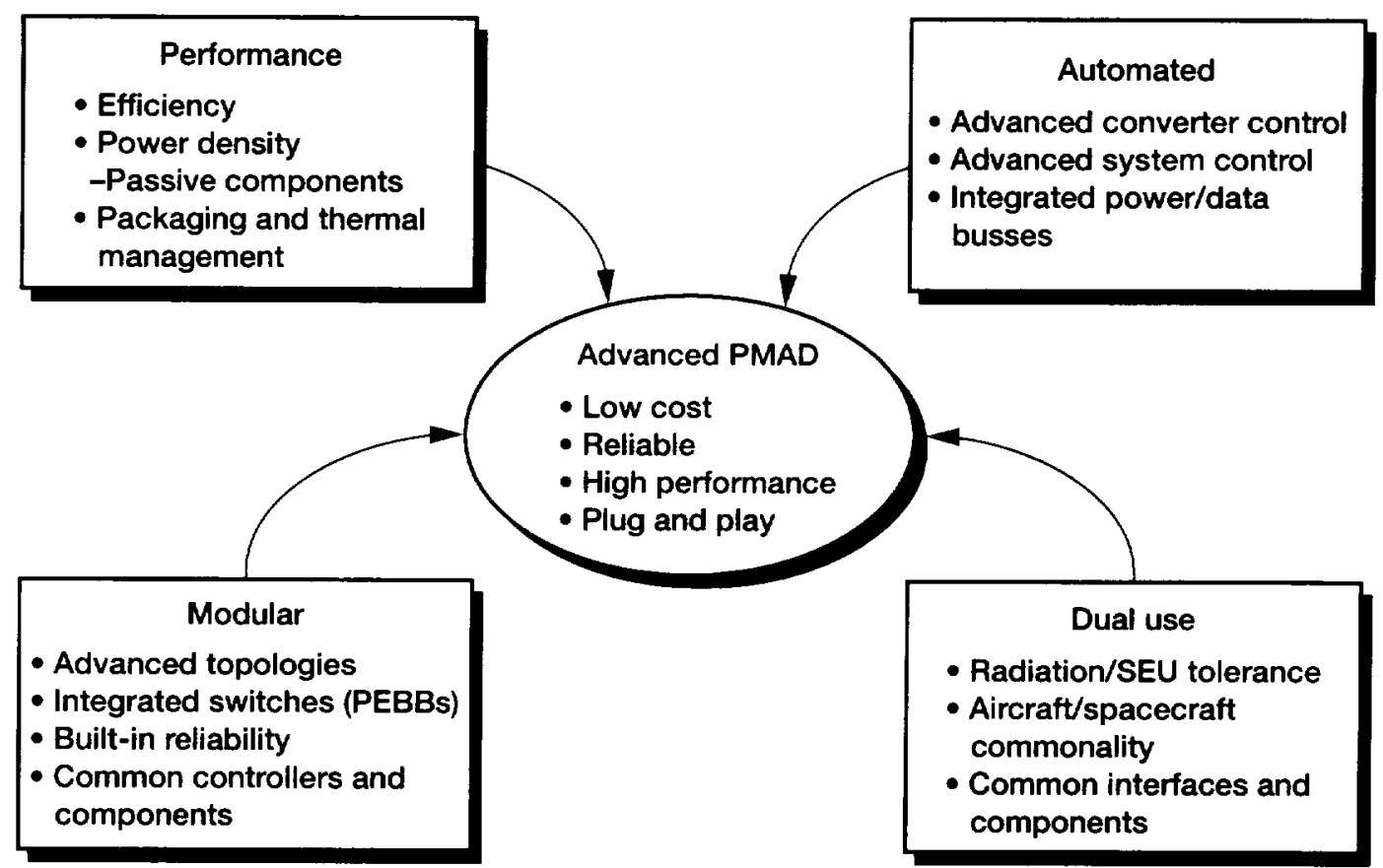

Figure 2.-Thrusts of Advanced Power Management and Distribution (PMAD). 
PPU = Power Processing Unit

$\mathrm{M} / \mathrm{G}=$ Motor $/$ Generator

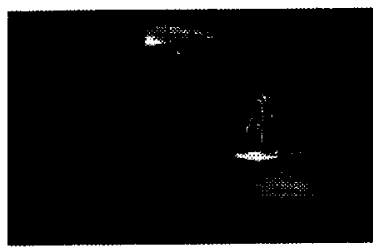

Earth Science (ES)

- Electric propulsion PPU

- Flywheel M/G electronics

- Solar array regulators

- Battery charge/discharge regulators

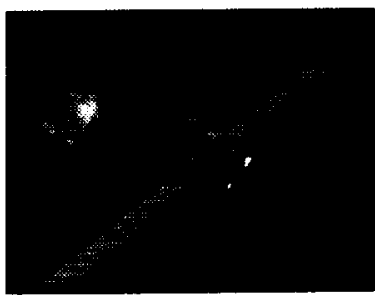

Space Science (SS)

- Electric propulsion PPU

- Flywheel M/G electronics

- Solar array regulators

- Battery charge/discharge regulators

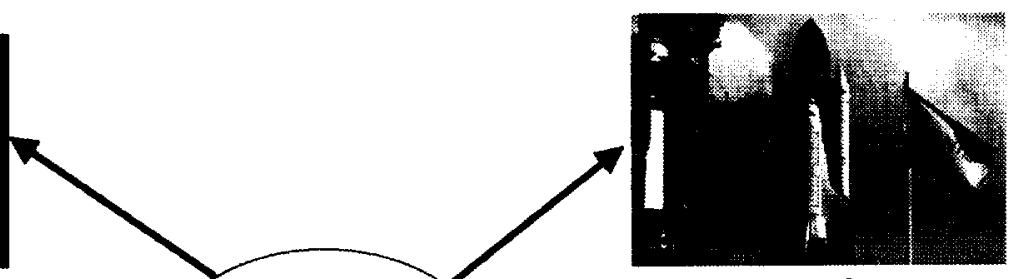

HEDS

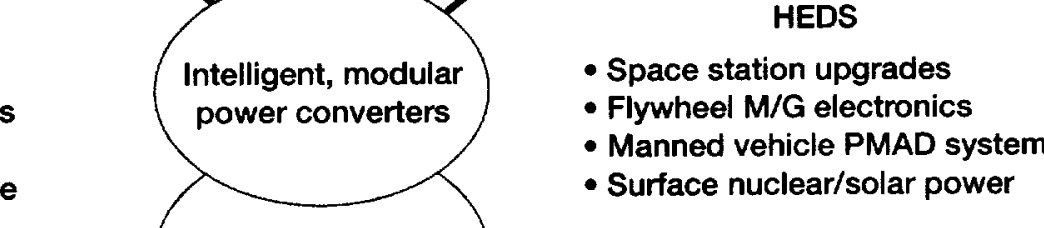

ligent motor drives

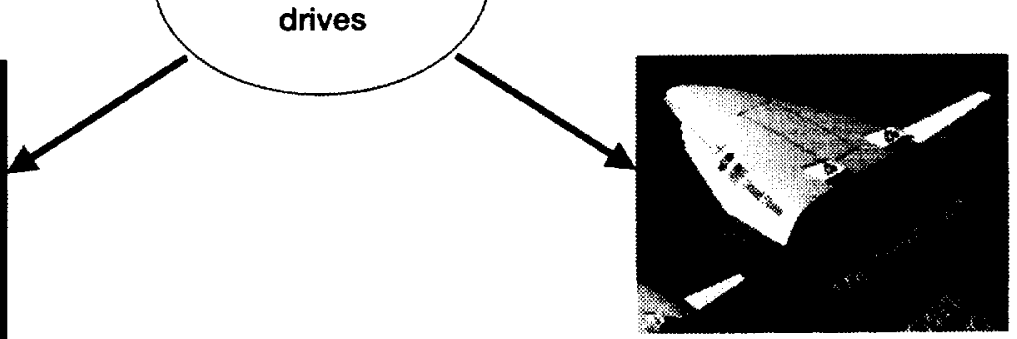

Transportation (AT)

- Electric actuators

- Flywheel M/G electronics

- Highly distributed power systems

Figure 3.-Relevance of Modular Systems to NASA Missions.

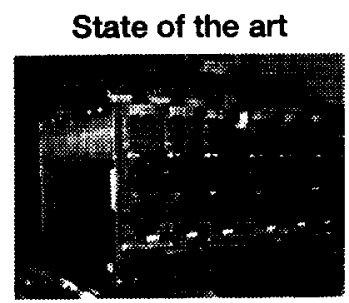

$300 \mathrm{~W} / \mathrm{kg}$

$1 \mathrm{~W} / \mathrm{cm}^{3}$

$150+$ parts

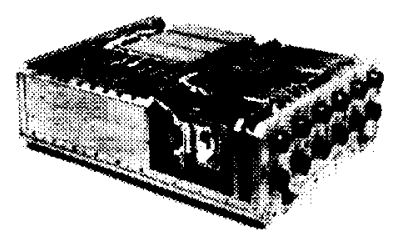

$250 \mathrm{~W} / \mathrm{kg}$

$0.31 \mathrm{~W} / \mathrm{cm}^{3}$

200 parts

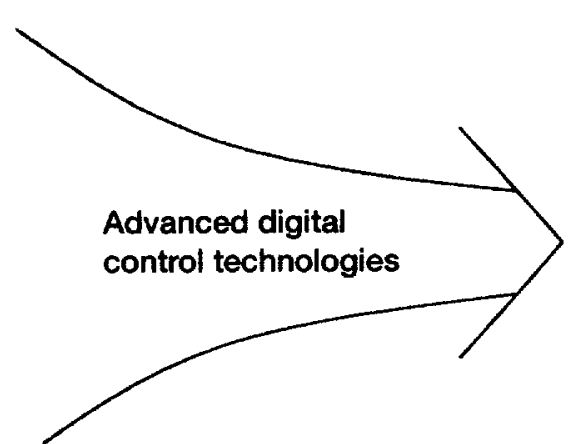

Benefits

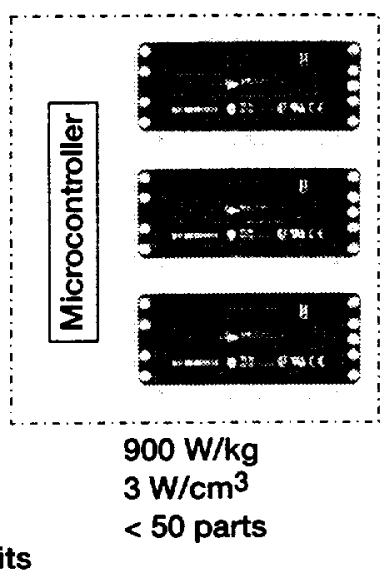

Power density is TRIPLED

Parts count reduced by $67 \% \rightarrow$ higher reliability

Improved fault tolerance through multiple master units

Figure 4.-Modularity-Derived Gains in Power Density and Parts Count. 
Improved touchdown

bearing spider assembly

ling line at upper touchdown bearing

Combination magnetic bearing coolant jacket

Rotor rim

Cooling line at lower touchdown bearing

Lower housing cover

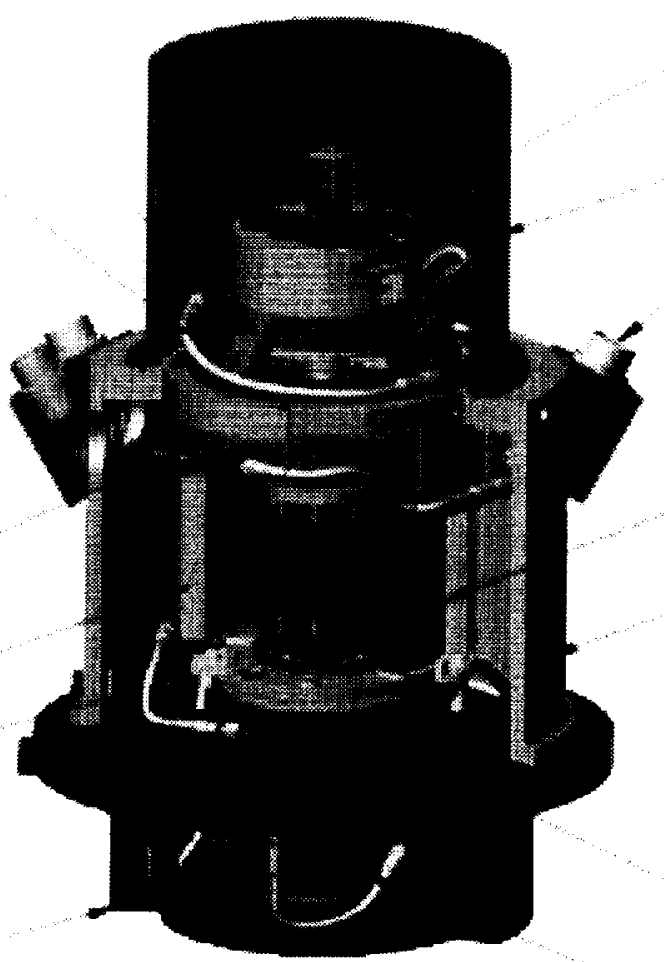

Internal sensor conditioning electronics board

Upper housing cover

Typical electrical connector interface to module

Rotor hub

Modified outer housing structure

Radial magnetic bearing coolant jacket

Improved touchdown bearing spider assembly

Figure 5.-Cut-Away View of Flywheel Module (courtesy of U. S. Flywheel).

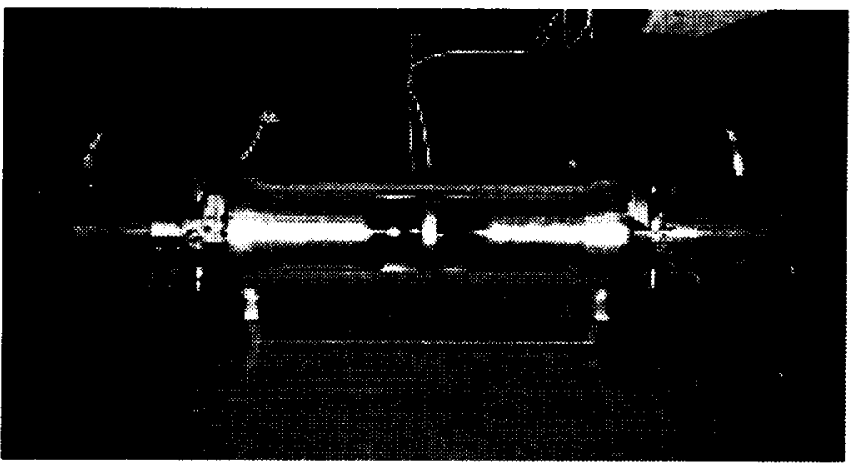

Figure 6.-Two Opposed 55We Stirling Converters on Test at STC (courtesy of STC). 


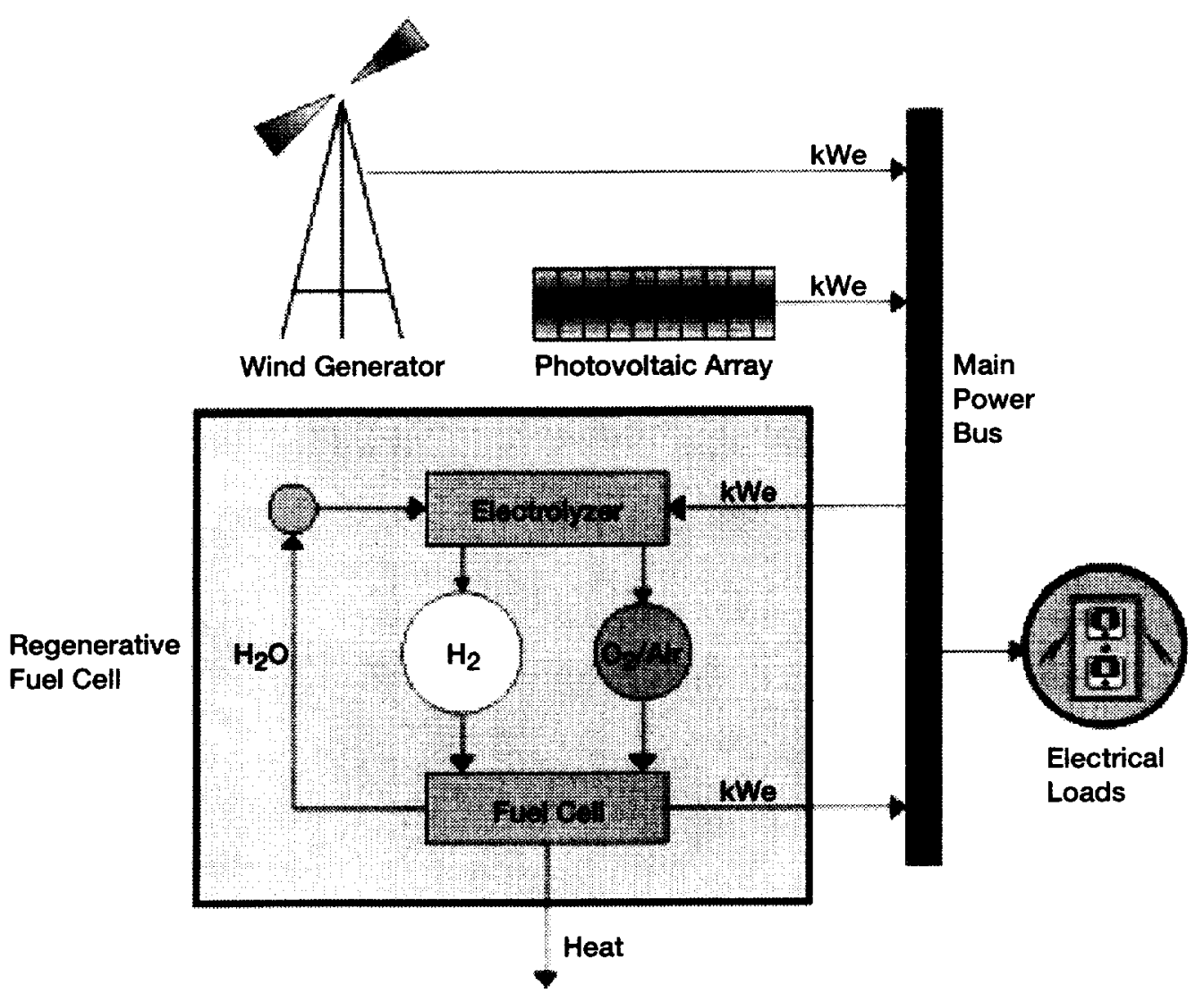

Figure 7.-Schematic of Regenerative Fuel Cell.

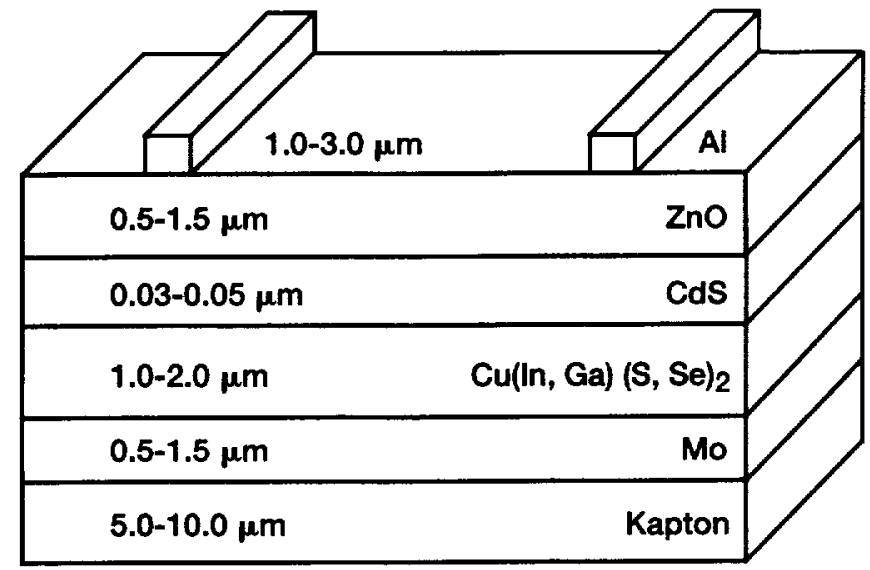

Figure 8. Structure of Molybdenum-on-Kapton-Based Photovoltaic Cell. 


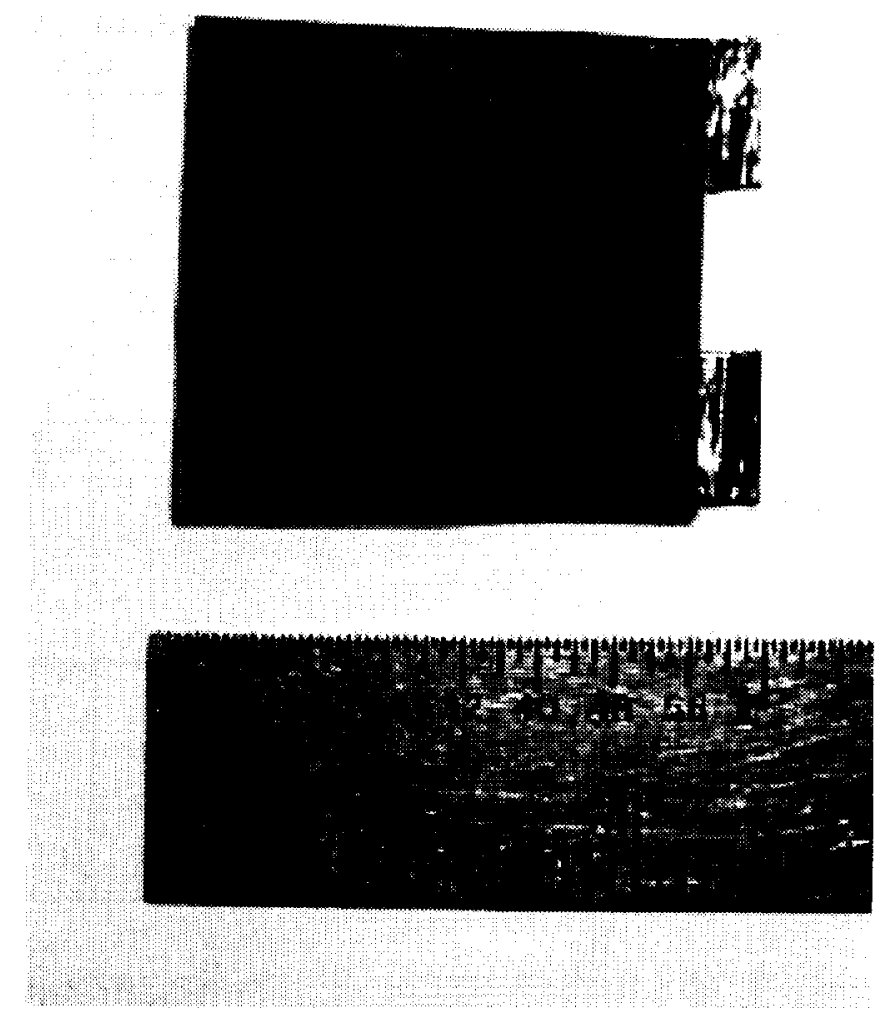

Figure 9.-Solid-State Lithium Battery (Mass: $0.5 \mathrm{gm}$ ).

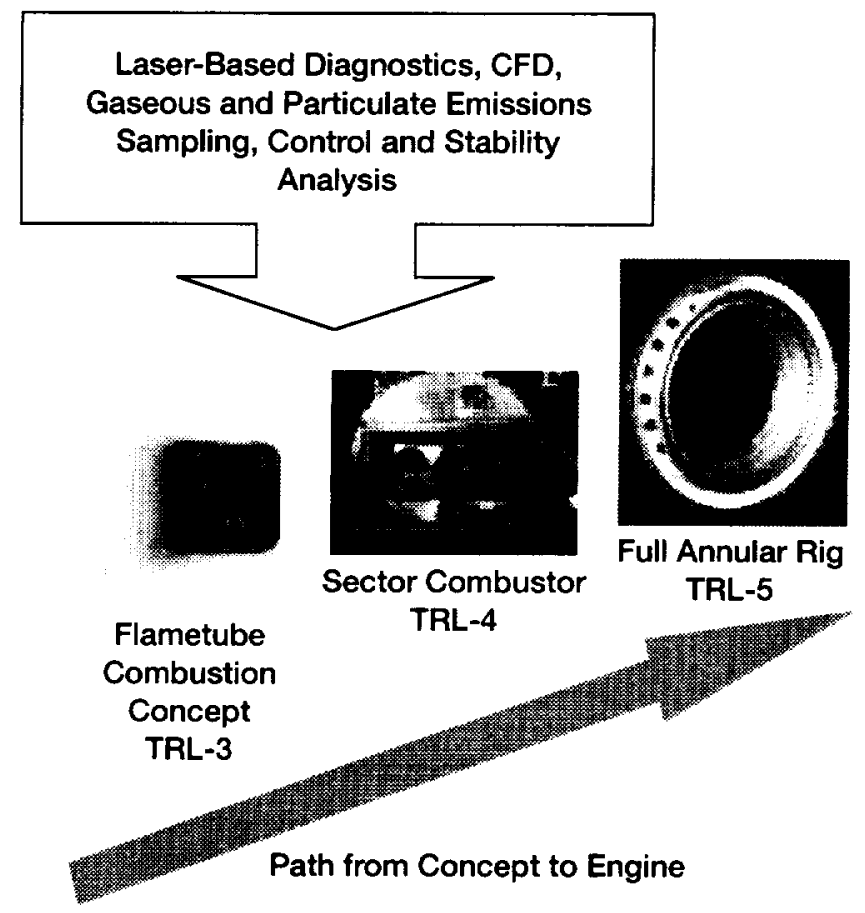

Figure 10.-Low $\mathrm{NO}_{x}$ Emmission Combustor Development. 
Public reporting burden for this collection of information is estimated to average 1 hour per response, including the time for reviewing instructions, searching existing data sources, gathering and maintaining the data needed, and completing and reviewing the collection of information. Send comments regarding this burden estimate or any other aspect of this collection of information, including suggestions for reducing this burden, to Washington Headquaners Services, Directorate for Information Operations and Repors, 20503.

\begin{tabular}{l|l|l}
\hline 1. AGENCY USE ONLY (Leave blank) & 2. REPORT DATE & 3. REPORT TYPE AND DATES COVERED
\end{tabular}

\begin{tabular}{|r|r|r} 
July 2000 & Technical Memorandum \\
\hline
\end{tabular}

\section{TITLE AND SUBTITLE}

\section{FUNDING NUMBERS}

\section{AUTHOR(S)}

M. David Kankam, Valerie J. Lyons, Mark A. Hoberecht, Robert R. Tacina, and Aloysius F. Hepp

7. PERFORMING ORGANIZATION NAME(S) AND ADDRESS(ES)

National Aeronautics and Space Administration

John H. Glenn Research Center at Lewis Field

Cleveland, Ohio 44135-3191

9. SPONSORINGMONITORING AGENCY NAME(S) AND ADDRESS(ES)

National Aeronautics and Space Administration

Washington, DC 20546-0001

$$
\text { WU }-632-6 \mathrm{~A}-1 \mathrm{~K}-00
$$

8. PERFORMING ORGANIZATION

REPORT NUMBER

E-12391

\section{SUPPLEMENTARY NOTES}

Prepared for the 35th Intersociety Energy Conversion Engineering Conference sponsored by the American Institute of Aeronautics and Astronautics, Las Vegas, Nevada, July 24-28, 2000. Responsible person, M. David Kankam, organization code $5450,(216)$ 433-6143.

12a. DISTRIBUTION/AVAILABILITY STATEMENT 12b. DISTRIBUTION CODE

Unclassified - Unlimited

Subject Categories: 20 and 44

Distribution: Standard

This publication is available from the NASA Center for AeroSpace Information, (301) 621-0390.

13. ABSTRACT (Maximum 200 words)

This paper is an overview of a wide range of recent aerospace technologies under development at the NASA Glenn Research Center, in collaboration with other NASA centers, government agencies, industry and academia. The focussed areas are space solar power, advanced power management and distribution systems, Stirling cycle conversion systems, fuel cells, advanced thin film photovoltaics and batteries, and combustion technologies. The aerospace-related objectives of the technologies are generation of space power, development of cost-effective and reliable, high performance power systems, cryogenic applications, energy storage, and reduction in gas-turbine emissions, with attendant clean jet engines. The terrestrial energy applications of the technologies include augmentation of bulk power in ground power distribution systems. and generation of residential, commercial and remote power, as well as promotion of pollution-free environment via reduction in combustion emissions.

\section{SUBJECT TERMS}

Batteries; Flywheels; Fuel cells; Photovoltaic cells; Power conditioning; Power converters; Solar dynamic power systems; Space power satellites; Stirling engines; Thin films; Combustors

\begin{tabular}{|c|c|c|}
\hline $\begin{array}{c}\text { 17. SECURITY CLASSIFICATION } \\
\text { OF REPORT } \\
\text { Unclassified }\end{array}$ & $\begin{array}{c}\text { 18. SECURITY CLASSIFICATION } \\
\text { OF THIS PAGE } \\
\text { Unclassified }\end{array}$ & $\begin{array}{c}\text { 19. SECURITY CLASSIFICATION } \\
\text { OF ABSTRACT } \\
\text { Unclassified }\end{array}$ \\
\hline
\end{tabular}

